\title{
Acute performance of a novel restorative transcatheter aortic valve: preclinical results
}

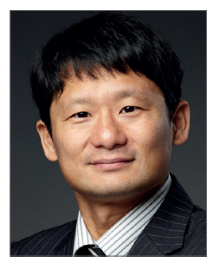

Yosuke Miyazaki ${ }^{1}, \mathrm{MD}, \mathrm{PhD}$; Osama I. Soliman ${ }^{1,2}, \mathrm{MD}, \mathrm{PhD}$;

Mohammad Abdelghani ${ }^{3}$, MD, MSc; Athanasios Katsikis ${ }^{4}, \mathrm{MD}, \mathrm{PhD}$; Christophe Naz ${ }^{5}$, MSc; Susana Lopes ${ }^{5}$, MSc; Boris Warnack ${ }^{5}$, PhD; Martijn Cox ${ }^{5}$, PhD; Yoshinobu Onuma ${ }^{1,2}, \mathrm{MD}, \mathrm{PhD}$; Patrick W. Serruys ${ }^{6 *}$, MD, PhD

1. Department of Cardiology, Thoraxcenter, Erasmus Medical Center Rotterdam, Rotterdam, the Netherlands; 2. Cardialysis, Rotterdam, the Netherlands; 3. Department of Cardiology, Academic Medical Center, University of Amsterdam, Amsterdam, the Netherlands, 4. 401 General Military Hospital of Athens, Department of Cardiology, Athens, Greece; 5. Xeltis, Eindhoven, the Netherlands; 6. NHLI, Imperial College London, London, United Kingdom

GUEST EDITOR: Alec Vahanian, MD, PhD; Department of Cardiology, Hôpital Bichat, and University Paris VII, Paris, France

\section{KEYWORDS \\ - aortic stenosis \\ - biodegradable \\ - echocardiography \\ - Endogenous Tissue \\ Restoration \\ - outcome \\ - transcatheter \\ aortic valve \\ implantation (TAVI) \\ - videodensitometry}

\begin{abstract}
Aims: The Xeltis aortic valve leaflets are made from a bioabsorbable supramolecular polymer that guides the tissue to restoring itself. It is mounted on a self-expanding nitinol frame that includes three feelers and a native leaflet clipping mechanism. We sought to investigate the acute valve performance in a preclinical setting.
\end{abstract}

Methods and results: In 33 sheep, $26 \mathrm{~mm}$ Xeltis aortic valves were transapically implanted in a $23 \mathrm{~mm}$ native annulus. Aortography (analysable, $n=28$ ) and echocardiography (analysable, $n=20$ ) images were acquired immediately after implantation of the Xeltis aortic valve to assess the acute device performance. On echocardiography, transvalvular peak pressure gradient (PG) was 7.4 (IQR: 6.0-8.9) $\mathrm{mmHg}$, mean PG was 4.0 (IQR: $3.0-5.0) \mathrm{mmHg}$, and effective orifice area was 2.2 (IQR: $1.6-2.5) \mathrm{cm}^{2}$. Trace $(\mathrm{n}=6)$, mild $(n=2)$ and no $(n=12)$ transvalvular aortic regurgitation $(A R)$ were seen. Likewise, no paravalvular AR was detected in 7 cases, whereas trace, mild and moderate were seen in 7, 5 and 1 cases, respectively. On quantitative videodensitometric AR (VD-AR) assessment, a median value of 6\% (IQR: 1-12\%) of AR was seen. Three cases had a VD-AR superior to $17 \%$, which has a prognostic significance. Out of these three cases, two had echocardiographic assessment available, which showed mild and moderate paravalvular regurgitation due to inadequate leaflet clipping.

Conclusions: In a transapical ovine model, the novel restorative transcatheter aortic valve with bioabsorbable leaflets demonstrated good haemodynamic performance comparable to commercially available devices. The highly porous polymeric leaflets demonstrated good competence immediately after implantation with no cases having >mild transvalvular AR.

\footnotetext{
*Corresponding author: Cardiovascular Science Division of the NHLI within Imperial College of Science, Technology and Medicine, South Kensington Campus, London, SW7 2AZ, United Kingdom.E-mail: patrick.w.j.c.serruys@pwserruys.com
} 


\section{Abbreviations}

AUC

CMR cardiovascular magnetic resonance

ETR Endogenous Tissue Restoration

IQR interquartile range

LV left ventricle

LVOT left ventricle outflow tract

PG pressure gradient

PVR paravalvular regurgitation

ROI region of interest

SD standard deviation

TAVI transcatheter aortic valve implantation

TDC time-density curve

VD-AR videodensitometric aortic regurgitation

VTI velocity time integral

\section{Introduction}

Transcatheter aortic valve implantation (TAVI) is an established treatment of aortic stenosis with expanding indications towards younger and lower-risk patients. However, durability concerns have emerged related to signals of an accelerated degeneration of transcatheter aortic valve leaflets, which represents the major barrier limiting TAVI expansion to new strata of patients ${ }^{1,2}$. Current bioprosthetic valves are made of animal-derived glutaraldehydefixed foreign material, which raises several issues, such as durability, thromboembolism, infection, stenosis and regurgitation. Tissue of animal origin tends to degenerate and becomes calcified with time; therefore, in the span of a lifetime, reintervention (re-operation) is frequent after one or two decades in patients who received bioprostheses implanted surgically or percutaneously ${ }^{3}$.

A restorative valve has been developed based on a novel technology called Endogenous Tissue Restoration (ETR). The principle of ETR is that a leaflet of a bioabsorbable material will be progressively replaced by endogenous tissue ${ }^{4}$. As schematically shown in Figure 1, the implant is created by electrospinning a bioabsorbable polymer to form a three-dimensional construct, such as a heart valve. The construct is implanted without adding any cells or growth factors, and is functional upon implantation. The porous microstructure of the implant allows cells to migrate into the construct, after which these cells start to produce neotissue that fills the pores and gradually takes over functionality from the gradually absorbing polymer. This new

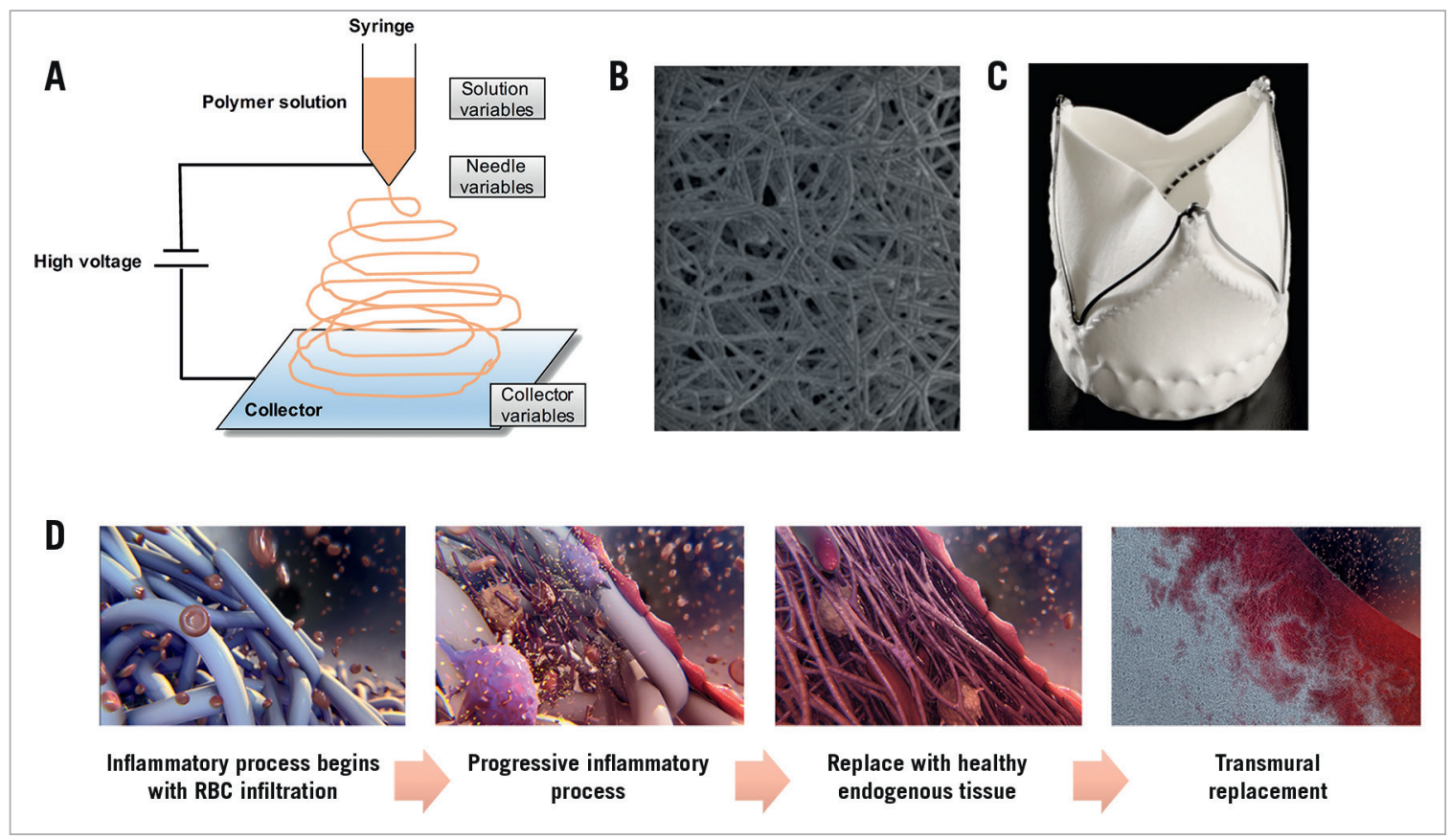

Figure 1. The principle of electrospinning and ETR of the Xeltis aortic valve. A) The principle of electrospinning: electrospinning is a widely used technique for the electrostatic production of nanofibres, during which electric power is used to make polymer fibres with diameters ranging from $2 \mathrm{~nm}$ to several micrometres from polymer solutions or melts. This process is a major focus of attention because of its versatility and ability to produce fibres continuously on a scale of nanometres, which is difficult to achieve using other standard technologies.

Electrospinning is a relatively simple way of creating nanofibre materials, but there are several parameters that can significantly influence the formation and structure of produced nanofibres. These parameters such as solution variables, needle variables or collector variables could be manipulated to produce the desired material. B) Electron microscopic images of the product of electrospinning. Reproduced and adapted with permission from Bockeria et al ${ }^{5}$. C) Leaflets with a porous microstructure made through the electrospinning process were mounted on a self-expanding nitinol frame that included three feelers and a native leaflet clipping mechanism. D) The principle of ETR: the Xeltis aortic valve is gradually infiltrated by blood elements (red cells, platelets, macrophages), myoblasts, fibroblasts with subsequent enzymatic bioabsorption of the fibres, and gradually replaced by endogenous tissue. 
technology could potentially overcome the issues of the currently available valves caused by the use of foreign material. A paediatric conduit (Fontan) and a pulmonary valved conduit with this technology were investigated in vitro, in a preclinical setting and are currently being tested in the clinical setting ${ }^{5,6}$. With regard to the extension of this technology to the aortic valve, this is the first report to investigate the acute performance of the Xeltis aortic valve (Xeltis BV, Eindhoven, the Netherlands).

Editorial, see page 1379

\section{Methods \\ STUDY DESIGN}

This preclinical study included 33 Ile de France sheep that received the Xeltis aortic valve by a transapical approach. The first seven sheep were used for iterative design optimisations, after which the Xeltis aortic valve was implanted in 26 sheep. This study reports the acute performance of the Xeltis aortic valve implanted in these 33 sheep. Post-implantation aortography was performed at the end of the procedure to evaluate the acute performance of the valve. Echocardiography was obtained after the procedure. The study was conducted in compliance with ISO 10993-2. The Animal Care and Use Committee of the testing facility is registered at the CNREEA under the Ethics Committee $n^{\circ} 37$.

\section{DESIGN AND IMPLANTATION OF THE XELTIS AORTIC VALVE}

The Xeltis aortic valve is made from a bioabsorbable supramolecular polymer. More specifically, polyester urethanes were used that contained the ureidopyrimidinone (UPy) supramolecular binding motif ${ }^{7}$. A key attribute of this class of material is that mechanical properties and absorption characteristics can be changed and tuned independently, thus allowing selection of the appropriate material configuration through a process of elimination and optimisation. Three polymer configurations were used to construct the Xeltis aortic valve in this study. The supramolecular polymers were used to synthesise the leaflets (through an electrospinning process) and the leaflets were mounted on a self-expanding nitinol frame that included three feelers and a native leaflet clipping mechanism. The extremities of the feelers were encapsulated with bioabsorbable materials to avoid damage to the leaflet, as seen in the first series of seven implants (Figure 1).

\section{IMPLANTATION PROCEDURE}

All procedures were performed under general anaesthesia. The Xeltis aortic valves were implanted by a transapical approach under the guidance of echocardiography, fluoroscopy and aortography. A pigtail catheter was introduced transfemorally and placed in the native aortic valve cusp as reference for positioning. The valve was delivered transapically using fluoroscopy guidance. The distal end of the valve was deployed first after which the delivery system was pulled gently to anchor the three device arms into the sinuses of Valsalva, prior to full deployment and release of the device (Figure 2).

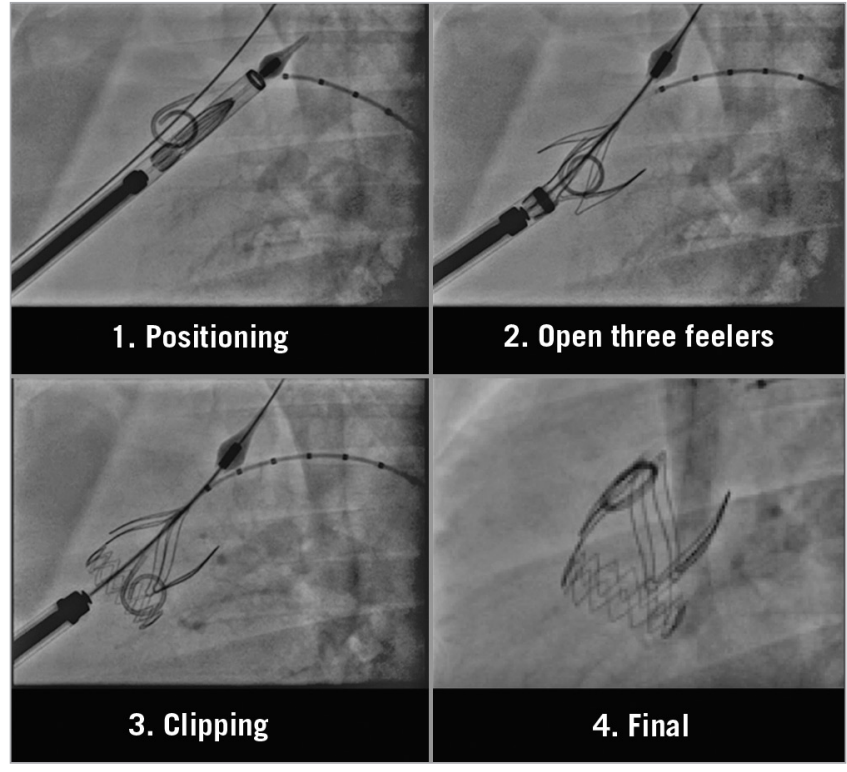

Figure 2. Implantation of the Xeltis aortic valve.

\section{QUANTIFICATION OF AORTIC REGURGITATION ASSESSMENT BY AORTOGRAPHY USING VIDEODENSITOMETRIC TECHNOLOGY}

Videodensitometric AR (VD-AR) was analysed at an independent core laboratory (Cardialysis Clinical Trials Management and Core Laboratories, Rotterdam, the Netherlands) by experienced observers who were blinded to echocardiogram results. A dedicated software (CAAS A-Valve 2.0.2; Pie Medical Imaging, Maastricht, the Netherlands) was used to quantify the regurgitation from angiograms. The details of this technique have been described elsewhere ${ }^{8-14}$. After delineating the aortic root (i.e., reference area) and the subaortic one third of the left ventricle (i.e., region of interest [ROI]), the contrast time-density curves (TDCs) were analysed both in the ROI (in the $\mathrm{LV}$ ) and in the reference region (the aortic root) during at least three cardiac cycles after contrast injection. The area under the curve (AUC) is automatically calculated and represents time-density integrals. VD-AR is automatically calculated as the ratio of the AUC of the time-density integrals measured in the ROI and the reference area. Theoretically, the value of VD-AR ranges from 0 to 1 (Figure 3).

\section{AORTIC REGURGITATION AND HAEMODYNAMIC DATA ASSESSMENT BY ECHOCARDIOGRAPHY}

Echocardiographic data were analysed in accordance with the recommendations of the American Society of Echocardiography/ European Association of Cardiovascular Imaging ${ }^{15-17}$. Mean and peak pressure gradients (PG) across the Xeltis aortic valve were derived from continuous wave Doppler evaluation of blood flow in the left ventricle outflow tract (LVOT) and across the prosthetic device by manual tracing of the timed integration of the velocity curve. Aortic valve area was calculated by continuity equation using the following measurements: 1) velocity time integral (VTI) from LVOT level measured by pulsed-wave Doppler, 2) velocity 


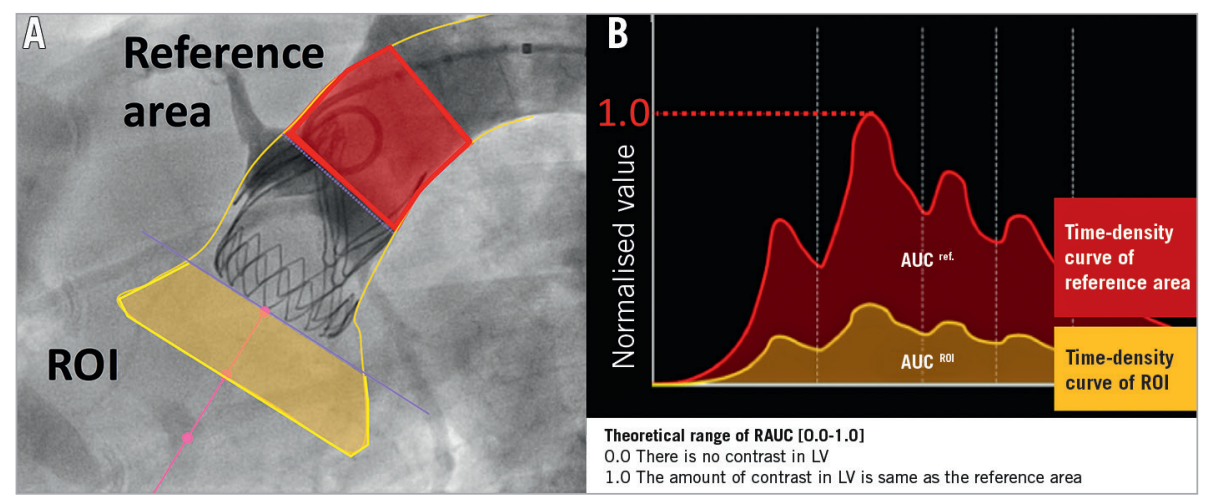

Figure 3. Videodensitometric assessment of aortic regurgitation. A) Delineation of the aortic root (reference area: red area in the aortography) and the subaortic one third of the LV (ROI: yellow area in the aortography) are shown by the analyser. B) The time-density curves are provided for both the ROI (yellow TDC) and the reference region (red TDC) and the AUC is automatically computed by the software time-density integrals. VD-AR corresponds to the relative AUC, which is automatically calculated as the ratio of the relative AUC (ROI [yellow] and reference area [red]). Theoretically, the value of VD-AR ranges from 0 to 1. Reproduced and adapted with permission from Tateishi et al ${ }^{13}$.

time integral (VTI) across aortic valve prosthesis level measured by continuous wave Doppler, and 3) diameter of the LVOT at the same location of pulsed-wave Doppler sample in the LVOT. For the assessment of aortic regurgitation (AR) severity and the origin of $\mathrm{AR}$, the core lab used a standard methodology as described earlier in several core lab publications ${ }^{18-20}$.

\section{STATISTICAL ANALYSIS}

When continuous variables were normally distributed, we summarised data as mean \pm standard deviation (SD). If they were not normally distributed, median and interquartile range (IQR) were used.

\section{Results}

Between April 2016 and October 2016, 33 devices with a diameter of $26 \mathrm{~mm}$ were implanted transapically in native annuli with an approximate diameter of $23 \mathrm{~mm}$. Aortography was performed after implantation of the Xeltis aortic valve in all 33 sheep. In order to assess the acute device performance, echocardiography was performed immediately after the procedure in twenty consecutive cases after the initial and purely angiographic assessment of the first 13 cases.

\section{PROCEDURAL SUCCESS}

Overall, there were no major complications in the majority of cases after TAVI procedure. However, two cases suffered from complications during the procedure because one of the feelers did not deploy well. A few cases showed issues in the subacute phase ( $>24 \mathrm{hrs}$ and $<2$ weeks), which were mainly related to 1) perforation of the native cusps due to improper coverage of the stent feelers, and 2) abrasion of the mitral valve against the aortic valve stent frame resulting in mitral insufficiency. In most cases, mitral valve abrasion was a consequence of stent migration due to perforation of the native cusps. Small improvements to the strut and frame protection were made during the study, which successfully eliminated these subacute issues.

\section{QUANTIFICATION OF AR AFTER IMPLANTATION}

Aortic regurgitation (AR) after implantation of the Xeltis aortic valve was quantified by videodensitometric assessment. Five animals were not analysable for the following reasons: 1) the ROI moved by deep breath $(\mathrm{n}=3)$, and 2$)$ the ROI was not included in the aortography $(n=2)$. Twenty-eight animals were analysable for this assessment. The median and IQR of VD-AR was $6 \%$ (1-12\%) (Figure 4). We compared the VD-AR in the first seven iterative cases with the next 26 cases. There were six (86\%) versus $22(79 \%)$ analysable cases for VD-AR in the first seven cases and the next 26 sheep, respectively. Median (IQR) VD-AR was $8 \%(1.8-9.8 \%)$ versus $5.5 \%(1.0-14.0 \%)$ in the first seven iterative cases and the next 26 sheep ( $\mathrm{p}=0.89)$, respectively. Three cases showed a regurgitation superior to $17 \%$, a value which has a prognostic significance in clinical practice ${ }^{13}$.

\section{ACUTE HAEMODYNAMIC PERFORMANCE}

Haemodynamic performance was assessed immediately after implantation of the Xeltis aortic valve in 20 cases. Transvalvular

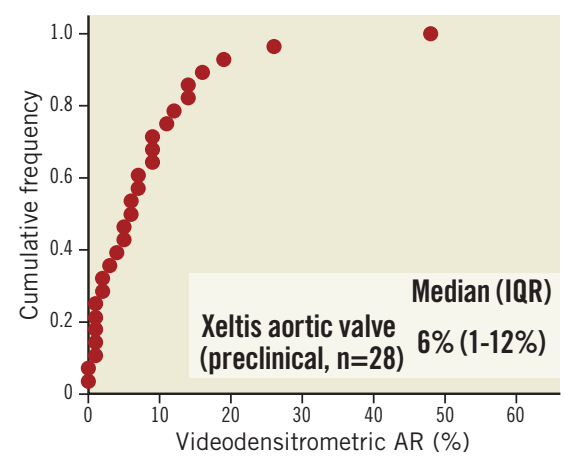

Figure 4. Cumulative frequency distribution curve of quantitative aortic regurgitation assessment (VD-AR) after implantation of the Xeltis aortic valve by videodensitometry. 
peak pressure gradient (PG) was $7.4(6.0-8.9) \mathrm{mmHg}$, mean PG was $4.0(3.0-5.0) \mathrm{mmHg}$, and effective orifice area was $2.2(1.6-2.5) \mathrm{cm}^{2}$ (Figure 5).

\section{SEVERITY OF AORTIC REGURGITATION BY ECHOCARDIOGRAPHY}

Twenty cases were analysable for the severity of paravalvular regurgitation (PVR) and transvalvular regurgitation by echocardiography. Seven cases were observed without any PVR. Seven cases had trace, five cases mild and one case moderate PVR. In terms of transvalvular regurgitation, 12 cases had none, six cases trace and two cases mild transvalvular regurgitation. Out of the three cases with videodensitometric assessment superior to $17 \%$, two had echocardiographic assessment available, which showed mild and moderate paravalvular regurgitation. These cases were attributed to inappropriate clipping of the leaflets.

\section{Discussion}

The main findings of this study are as follows. 1) The Xeltis aortic valves were implanted safely via the transapical approach. 2) The haemodynamic performance immediately after implantation of the Xeltis aortic valve was good compared to the objective performance indices of the current commercially available bioprosthetic valves. 3) Substantial regurgitation was observed in three cases; however, those cases of paravalvular regurgitation were due to the inadequate clipping of the leaflets. 4) Apart from these cases, only less than mild transvalvular regurgitation was observed.

\section{ADDED VALUE OF THE XELTIS AORTIC VALVE}

TAVI was primarily introduced for treating elderly high-risk patients with severe aortic stenosis. Because of limited life expectancy, there was less focus on the long-term durability ${ }^{21}$. However, patient selection for TAVI has increasingly expanded to younger and/or lower surgical risk patients ${ }^{22}$. Therefore, the long-term durability of TAVI prostheses became important. Although most of the currently available studies have not shown significant deterioration-related problems, longer-term data in large cohorts are needed ${ }^{21}$.
Current bioprosthetic valves are based on animal-derived glutaraldehyde-fixed pericardial tissue, and have been known to lead to biocompatibility concerns due to chronic inflammatory responses. The chronic inflammation could lead to calcification through secretion of cytokines by macrophages, such as osteopontin ${ }^{23-25}$. As clinical consequences, there is a need for adjunctive pharmacotherapy (long-term aspirin therapy and short-term systemic anticoagulation $)^{26-28}$ and repeat hospitalisations with or without reinterventions. ETR technology is based on the fact that a leaflet of a bioabsorbable material will be progressively replaced by endogenous tissue. Therefore, ETR could improve biocompatibility, resulting in less leaflet thickening and, in addition, less valve leaflet thrombosis and thus less need for antithrombotic therapy. Thus, this valve could potentially overcome the issues of the currently available valves caused by the use of foreign material.

\section{ANGIOGRAPHIC AORTIC REGURGITATION AFTER IMPLANTATION}

The leaflets of the Xeltis aortic valve are constructed by electrospinning, so that the leaflet has a porous texture due to the random assembly of microfibres (Figure 1). Therefore, the concern that transvalvular (trans-leaflet) AR could be initially present existed. In fact, in the large majority of cases, the videodensitometry of the outflow tract just detected trace contrast medium. During surgical reconstruction of RVOT in clinical cases, the surgical operator is used to witnessing oozing of the blood through the wall of the conduit, but almost instantaneously haemostasis is achieved. Red cell, fibrin and protein get caught in the fibre network and render the leaflets competent and no longer permeable to the angiographic contrast medium.

\section{ECHOCARDIOGRAPHIC AORTIC REGURGITATION AFTER IMPLANTATION}

More than mild transvalvular regurgitation was not observed by echocardiography. Although quantitative assessment of regurgitation by aortography indicated that three cases had a regurgitation
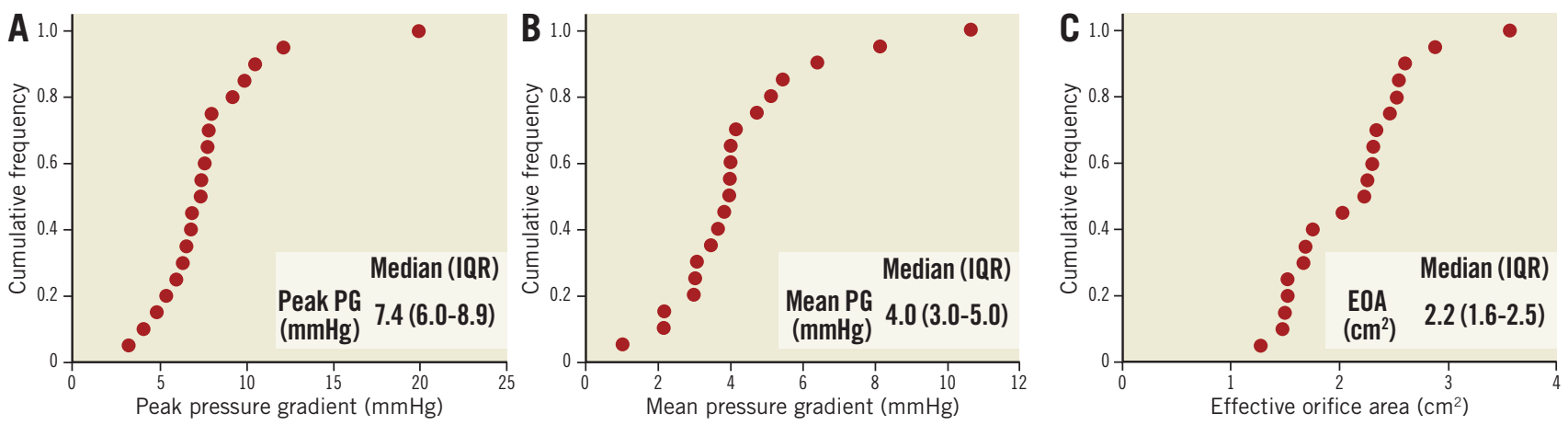

Figure 5. Haemodynamic performance after implantation of the Xeltis aortic valve. Cumulative frequency and median value of A) peak pressure gradient across the valve, B) mean pressure gradient across the valve, and C) effective orifice area immediately after implantation of the Xeltis aortic valve. 
superior to the critical level of $17 \%$, AR of two of these cases by echocardiography was shown to originate from paravalvular leaks due to inadequate clipping of native leaflets.

\section{COMPARISON WITH CURRENTLY AVAILABLE BIOPROSTHETIC VALVES}

Spethmann et al reported the haemodynamic performance after implantation of the Edwards SAPIEN (Edwards Lifesciences, Irvine, CA, USA) and CoreValve ${ }^{\circledR}$ (Medtronic, Minneapolis, MN, USA), and Soliman et al reported the haemodynamic data after implantation of the LOTUSTM (Boston Scientific, Marlborough, MA, USA) and SAPIEN 3 (Edwards Lifesciences) based on echocardiography ${ }^{18,29}$ (Table 1). The severity of AR after implantation of the Xeltis aortic valve quantified by videodensitometry using aortography was compared to that of current commercially available valves, which were assessed in the Brazilian TAVI registry ${ }^{13}$. VD-AR of the Xeltis aortic valve $(6 \%$ [1-12]) was less than that of the SAPIEN XT (Edwards Lifesciences) (10\% [5-14]) and the CoreValve (13\% [7-22]), and was similar to that of the LOTUS bioprosthetic valve (3\% [1-7]) (unpublished data). Although the current study was performed in a preclinical setting, and compared to the haemodynamic parameters reported in a clinical setting, the acute haemodynamic performance was good.

Table 1. Comparison of haemodynamic data between current commercially available valves and the Xeltis aortic valve.

\begin{tabular}{|l|c|c|c|c|c|}
\hline & \multicolumn{4}{|c|}{ Human data from clinical trial } & $\begin{array}{c}\text { Preclinical } \\
\text { data from } \\
\text { normal } \\
\text { sheep }\end{array}$ \\
\cline { 2 - 6 } & $\begin{array}{c}\text { Edwards SAPIEN } \\
(26 ~ m m)^{29}\end{array}$ & $\begin{array}{c}\text { CoreValve } \\
(\mathbf{2 6 ~ m m})^{29}\end{array}$ & LOTUS $^{18}$ & $\begin{array}{c}\text { SAPIEN } \\
\mathbf{3}^{18}\end{array}$ & Xeltis \\
\hline $\begin{array}{l}\text { Peak pressure } \\
\text { gradient (mmHg) }\end{array}$ & 15.8 & 15.5 & 20 & 18 & 7.4 \\
\hline $\begin{array}{l}\text { Mean pressure } \\
\text { gradient (mmHg) }\end{array}$ & 8.5 & 8.4 & 11 & 10 & 4.0 \\
\hline THV EOA (cm²) & 1.82 & 1.78 & 1.84 & 1.99 & 2.2 \\
\hline EOA: effective orifice area; THV: transcatheter heart valve \\
\hline
\end{tabular}

\section{Limitations}

First of all, although there was an attempt to make a large animal model with aortic stenosis ${ }^{30}$, there are no well-standardised large animal models of aortic stenosis. Furthermore, while reasonable efforts should be made to mimic the human situation, it should be realised that there will always be differences between human and animal models. In our specific case, there were several challenges specific to the use of the sheep model that we were successful in solving. First, sheep have a very short aortic root, and therefore limited space for positioning the valve. In addition, the sheep aortic and mitral valves are very close to each other and reside in the same plane. These challenges might lead to an ill-positioned or too long aortic valve prosthesis, which may cause mitral valve damage because of abrasion against the aortic valve prosthesis. We were able to solve this by using a short design of the prosthesis and appropriate cushioning of parts that are at risk of causing abrasion. Another challenge relates to the absence of stenosis and calcification, which means that the sheep aortic valve cusps are very thin and fragile compared to human aortic valve cusps, which are typically thick and calcified in cases of severe aortic stenosis. Since the position of our valve is based on feelers that sit on the native cusps, further cushioning was required to avoid perforation of these thin native cusps by the feelers. For the purpose of assessing the Xeltis aortic valve leaflets, a reasonable effort in developing and optimising the ovine model has been made. However, taking into account the usage of normal animals for the current experiments, the acute performance of the Xeltis aortic valve could be different between a non-aortic stenosis recipient and an aortic stenosis recipient, suggesting that further investigations are needed for confirmation.

\section{Conclusions}

In a transapical ovine model, the novel transcatheter aortic valve with restorative leaflets demonstrated good haemodynamic performance. The haemodynamics of the valve are comparable to the commercially available valves implanted in clinical cases. The highly porous polymeric leaflets demonstrated very good competence immediately after implantation with no cases having a more than mild transvalvular aortic regurgitation.

\section{Impact on daily practice}

The current study showed that the acute results of the Xeltis aortic valve were good in a preclinical setting. Although longterm results should be investigated, the restorative valve could have the potential to overcome the issues of current commercially available bioprosthetic valves.

\section{Guest Editor}

This paper was guest edited by Alec Vahanian, MD, PhD; Department of Cardiology, Hôpital Bichat, Paris and University Paris VII, Paris, France.

\section{Conflict of interest statement}

C. Naz, S. Lopes, B. Warnack and M. Cox are employed by Xeltis. P.W. Serruys is a member of the Advisory Board of Xeltis. The other authors have no conflicts of interest to declare. The Guest Editor is a consultant for Edwards Lifesciences.

\section{References}

1. Spagnolo P, Giglio M, Di Marco D, Latib A, Besana F, Chieffo A, Montorfano M, Sironi S, Alfieri O, Colombo A. Feasibility of ultra-low contrast 64-slice computed tomography angiography before transcatheter aortic valve implantation: a real-world experience. Eur Heart J Cardiovasc Imaging. 2016;17:24-33.

2. Abdelghani M, Serruys PW. Transcatheter Aortic Valve Implantation in Lower-Risk Patients With Aortic Stenosis: Is It 
Justified to Be the Preferred Treatment? Circ Cardiovasc Interv. 2016;9:e002944.

3. Bourguignon T, Bouquiaux-Stablo AL, Candolfi P, Mirza A, Loardi C, May MA, El-Khoury R, Marchand M, Aupart M. Very long-term outcomes of the Carpentier-Edwards Perimount valve in aortic position. Ann Thorac Surg. 2015;99:831-7.

4. Serruys PW, Miyazaki Y, Katsikis A, Abdelghani M, Leon MB, Virmani R, Carrel T, Cox M, Onuma Y, Soliman OII. Restorative valve therapy by endogenous tissue restoration: tomorrow's world? Reflection on the EuroPCR 2017 session on endogenous tissue restoration. EuroIntervention. 2017;13: AA68-AA77.

5. Bockeria LA, Svanidze O, Kim A, Shatalov K, Makarenko V, Cox M, Carrel T. Total cavopulmonary connection with a new bioabsorbable vascular graft: First clinical experience. J Thorac Cardiovasc Surg. 2017;153:1542-50.

6. Kluin J, Talacua H, Smits AI, Emmert MY, Brugmans MC, Fioretta ES, Dijkman PE, Sontjens SH, Duijvelshoff R, Dekker S, Janssen-van den Broek MW, Lintas V, Vink A, Hoerstrup SP, Janssen HM, Dankers PY, Baaijens FP, Bouten CV. In situ heart valve tissue engineering using a bioresorbable elastomeric implant - From material design to 12 months follow-up in sheep. Biomaterials. 2017;125:101-7.

7. Sijbesma RP, Beijer FH, Brunsveld L, Folmer BJ, Hirschberg JH, Lange RF, Lowe JK, Meijer EW. Reversible polymers formed from self-complementary monomers using quadruple hydrogen bonding. Science. 1997;278:1601-4.

8. Schultz CJ, Slots TL, Yong G, Aben JP, Van Mieghem N, Swaans M, Rahhab Z, El Faquir N, van Geuns R, Mast G, Zijlstra F, de Jaegere PP. An objective and reproducible method for quantification of aortic regurgitation after TAVI. EuroIntervention. 2014; 10:355-63.

9. Abdelghani M, Miyazaki Y, de Boer ES, Aben JP, van Sloun M, Suchecki T, van 't Veer M, Soliman O, Onuma Y, de Winter R, Tonino PAL, Rutten MCM, van de Vosse FN, Serruys PW. Videodensitometric quantification of paravalvular regurgitation of a transcatheter aortic valve: in-vitro validation. EuroIntervention. 2017 Oct 10. [Epub ahead of print].

10. Miyazaki Y, Abdelghani M, de Boer ES, Aben JP, van Sloun M, Suchecki T, van 't Veer M, Collet C, Asano T, Katagiri Y, Tenekecioglu E, Soliman OII, Onuma Y, de Winter R, Tonino P, van de Vosse FN, Rutten MCM, Serruys PW. A novel synchronized diastolic injection method to reduce contrast volume during aortography for aortic regurgitation assessment: in-vitro experiment of a transcatheter heart valve model. EuroIntervention. 2017 Jul 11. [Epub ahead of print].

11. Abdelghani M, Tateishi $\mathrm{H}$, Miyazaki $\mathrm{Y}$, Cavalcante $\mathrm{R}$, Soliman OI, Tijssen JG, de Winter RJ, Baan J Jr, Onuma Y, Campos CM, Leite RS, Mangione JA, Abizaid A, Lemos PA, de Brito FS Jr, Serruys PW. Angiographic assessment of aortic regurgitation by video-densitometry in the setting of TAVI: Echocardiographic and clinical correlates. Catheter Cardiovasc Interv. 2017;90:650-9.
12. Abdelghani M, Soliman OI, Schultz C, Vahanian A, Serruys PW. Adjudicating paravalvular leaks of transcatheter aortic valves: a critical appraisal. Eur Heart J. 2016;37:2627-44.

13. Tateishi H, Campos CM, Abdelghani M, Leite RS, Mangione JA, Bary L, Soliman OI, Spitzer E, Perin MA, Onuma Y, Serruys PW, Lemos PA, Brito FS Jr. Video densitometric assessment of aortic regurgitation after transcatheter aortic valve implantation: results from the Brazilian TAVI registry. EuroIntervention. 2016;11:1409-18.

14. Tateishi $\mathrm{H}$, Abdelghani $\mathrm{M}$, Cavalcante R, Miyazaki $\mathrm{Y}$, Campos CM, Collet C, Slots TL, Leite RS, Mangione JA, Abizaid A, Soliman OI, Spitzer E, Onuma Y, Serruys PW, Lemos PA, de Brito FS Jr. The interaction of de novo and pre-existing aortic regurgitation after TAVI: insights from a new quantitative aortographic technique. EuroIntervention. 2017;13:60-8.

15. Baumgartner $\mathrm{H}$, Hung $\mathrm{J}$, Bermejo J, Chambers JB, Evangelista A, Griffin BP, Iung B, Otto CM, Pellikka PA, Quinones M; American Society of Echocardiography; European Association of Echocardiography. Echocardiographic assessment of valve stenosis: EAE/ASE recommendations for clinical practice. J Am Soc Echocardiogr. 2009;22:1-23.

16. Zoghbi WA, Chambers JB, Dumesnil JG, Foster E, Gottdiener JS, Grayburn PA, Khandheria BK, Levine RA, Marx GR, Miller FA Jr, Nakatani S, Quinones MA, Rakowski H, Rodriguez LL, Swaminathan M, Waggoner AD, Weissman NJ, Zabalgoitia M; American Society of Echocardiography's Guidelines and Standards Committee; Task Force on Prosthetic Valves; American College of Cardiology Cardiovascular Imaging Committee; Cardiac Imaging Committee of the American Heart Association; European Association of Echocardiography; European Society of Cardiology; Japanese Society of Echocardiography; Canadian Society of Echocardiography; American College of Cardiology Foundation; American Heart Association; European Association of Echocardiography; European Society of Cardiology; Japanese Society of Echocardiography; Canadian Society of Echocardiography. Recommendations for evaluation of prosthetic valves with echocardiography and doppler ultrasound: a report From the American Society of Echocardiography's Guidelines and Standards Committee and the Task Force on Prosthetic Valves, developed in conjunction with the American College of Cardiology Cardiovascular Imaging Committee, Cardiac Imaging Committee of the American Heart Association, the European Association of Echocardiography, a registered branch of the European Society of Cardiology, the Japanese Society of Echocardiography and the Canadian Society of Echocardiography, endorsed by the American College of Cardiology Foundation, American Heart Association, European Association of Echocardiography, a registered branch of the European Society of Cardiology, the Japanese Society of Echocardiography, and Canadian Society of Echocardiography. J Am Soc Echocardiogr. 2009;22:975-1014.

17. Lang RM, Badano LP, Mor-Avi V, Afilalo J, Armstrong A, Ernande L, Flachskampf FA, Foster E, Goldstein SA, Kuznetsova T, Lancellotti P, Muraru D, Picard MH, Rietzschel ER, Rudski L, 
Spencer KT, Tsang W, Voigt JU. Recommendations for cardiac chamber quantification by echocardiography in adults: an update from the American Society of Echocardiography and the European Association of Cardiovascular Imaging. Eur Heart J Cardiovasc Imaging. 2015;16:233-70.

18. Soliman OI, El Faquir N, Ren B, Spitzer E, van Gils L, Jonker H, Geleijnse ML, van Es GA, Tijssen JG, van Mieghem NM, de Jaegere PP. Comparison of valve performance of the mechanically expanding Lotus and the balloon-expanded SAPIEN3 transcatheter heart valves: an observational study with independent core laboratory analysis. Eur Heart J Cardiovasc Imaging. 2017 Jan 6. [Epub ahead of print].

19. Di Martino LFM, Soliman OII, van Gils L, Vletter WB, Van Mieghem NM, Ren B, Galema TW, Schultz C, de Jaegere PPT, Di Biase M, Geleijnse ML. Relation between calcium burden, echocardiographic stent frame eccentricity and paravalvular leakage after corevalve transcatheter aortic valve implantation. Eur Heart J Cardiovasc Imaging. 2017;18:648-53.

20. Geleijnse ML, Di Martino LF, Vletter WB, Ren B, Galema TW, Van Mieghem NM, de Jaegere PP, Soliman OI. Limitations and difficulties of echocardiographic short-axis assessment of paravalvular leakage after corevalve transcatheter aortic valve implantation. Cardiovasc Ultrasound. 2016;14:37.

21. Arsalan M, Walther T. Durability of prostheses for transcatheter aortic valve implantation. Nat Rev Cardiol. 2016;13: 360-7.

22. Reardon MJ, Van Mieghem NM, Popma JJ, Kleiman NS, Sondergaard L, Mumtaz M, Adams DH, Deeb GM, Maini B, Gada H, Chetcuti S, Gleason T, Heiser J, Lange R, Merhi W, Oh JK, Olsen PS, Piazza N, Williams $M$, Windecker S, Yakubov SJ, Grube E, Makkar R, Lee JS, Conte J, Vang E, Nguyen H, Chang Y, Mugglin AS, Serruys PW, Kappetein AP; SURTAVI Investigators. Surgical or Transcatheter Aortic-Valve Replacement in Intermediate-Risk Patients. N Engl J Med. 2017; 376:1321-31.

23. Cho HJ, Cho HJ, Kim HS. Osteopontin: a multifunctional protein at the crossroads of inflammation, atherosclerosis, and vascular calcification. Curr Atheroscler Rep. 2009;11:206-13.

24. Scatena M, Liaw L, Giachelli CM. Osteopontin: a multifunctional molecule regulating chronic inflammation and vascular disease. Arterioscler Thromb Vasc Biol. 2007;27:2302-9.
25. Manji RA, Ekser B, Menkis AH, Cooper DK. Bioprosthetic heart valves of the future. Xenotransplantation. 2014;21:1-10.

26. Nishimura RA, Otto CM, Bonow RO, Carabello BA, Erwin JP 3rd, Guyton RA, O'Gara PT, Ruiz CE, Skubas NJ, Sorajja P, Sundt TM 3rd, Thomas JD; American College of Cardiology/ American Heart Association Task Force on Practice Guidelines. 2014 AHA/ACC guideline for the management of patients with valvular heart disease: executive summary: a report of the American College of Cardiology/American Heart Association Task Force on Practice Guidelines. J Am Coll Cardiol. 2014;63: 2438-88.

27. Nishimura RA, Otto CM, Bonow RO, Carabello BA, Erwin JP 3rd, Fleisher LA, Jneid H, Mack MJ, McLeod CJ, O'Gara PT, Rigolin VH, Sundt TM 3rd, Thompson A. 2017 AHA/ACC Focused Update of the 2014 AHA/ACC Guideline for the Management of Patients With Valvular Heart Disease: A Report of the American College of Cardiology/American Heart Association Task Force on Clinical Practice Guidelines. J Am Coll Cardiol. 2017;70:252-89.

28. Vahanian A, Alfieri O, Andreotti F, Antunes MJ, BaronEsquivias G, Baumgartner H, Borger MA, Carrel TP, De Bonis M, Evangelista A, Falk V, Lung B, Lancellotti P, Pierard L, Price S, Schäfers HJ, Schuler G, Stepinska J, Swedberg K, Takkenberg J, Von Oppell UO, Windecker S, Zamorano JL, Zembala M; ESC Committee for Practice Guidelines (CPG); Joint Task Force on the Management of Valvular Heart Disease of the European Society of Cardiology (ESC); European Association for Cardio-Thoracic Surgery (EACTS). Guidelines on the management of valvular heart disease (version 2012): the Joint Task Force on the Management of Valvular Heart Disease of the European Society of Cardiology (ESC) and the European Association for CardioThoracic Surgery (EACTS). Eur J Cardiothorac Surg. 2012;42: S1-44.

29. Spethmann S, Dreger H, Schattke S, Baldenhofer G, Saghabalyan D, Stangl V, Laule M, Baumann G, Stangl K, Knebel F. Doppler haemodynamics and effective orifice areas of Edwards SAPIEN and CoreValve transcatheter aortic valves. Eur Heart $J$ Cardiovasc Imaging. 2012;13:690-6.

30. Anderson CA, Wood WC, DiBernardo L, Erdmann M, Kypson AP. An acute animal model of aortic stenosis: initial attempts at leaflet modification. J Heart Valve Dis. 2012;21:172-4. 